\title{
Glacigenic postglacial faulting at Saint John, New Brunswick
}

\author{
B.E. Broster and K.B.S. Burke \\ Department of Geology, University of New Brunswick, P.O. Box 4400, \\ Fredericton, New Brunswick E3B 5A3, Canada \\ Date received February 14, 1990 \\ Date accepted June 1, 1990
}

\begin{abstract}
Displaced glacial striae were examined at outcrops within the central area of Saint John, New Brunswick. Displacements are mostly confined to north-facing slopes of small bedrock hills left after the glacial erosion of Cambrian-Early Ordovician rocks in the southeast limb of a syncline. The striae are generally of fset by high-angle reverse faults a few metres in length and with throws up to $60 \mathrm{~mm}$. The faults trend parallel to bedding and dip southward at angles similar to the dip of individual beds.

The displacements have long been considered as evidence of postglacial tectonic stresses in the area. However, from a detailed analysis of the extent and orientation of the small faults, we propose that the displacements represent the response of multilayered sedimentary rocks with anisotropic strengths, todifferential rates of glacitectonic loading and unloading. Therefore, the last major displacements likely occurred very soon after deglaciation of the area.
\end{abstract}

On a examiné les déplacements affectant des striures glaciaires sur des affleurements situés en plein centre de Saint-Jean, au Nouveau-Brunswick. Ces déplacements sont surtout confinés aux versants nord de petits môles modelés par l'érosion glaciaire des roches cambriennes à éo-ordoviciennes dans le flanc sud-est d'un synclinal. Les striures sont généralement affectées par des failles inverses à fort pendage, d'une longueur de quelques mètres et dont le rejet atteint $60 \mathrm{~mm}$. Les failles sont parallèles au litage et penchent vers le sud avec des inclinaisons semblables aux pendages des lits individuels.

On a longtemps vu dans ces déplacements le signe évident de contraintes tectoniques postglaciaires dans cette région. Cependant, une analyse détaillée de l'étendue et de l'orientation des petites failles nous permet d'avancer que les déplacements représentent la réponse de roches sédimentaires, disposées en couches multiples et dotées de résistances anisotropes, à divers taux de chargement et de délestage glaciotectoniques. Les demiers déplacements majeurs se manifestèrent vraisemblablement très tôt après la déglaciation de la région.

[Traduit par le journal]

\section{INTRODUCTION}

The analysis of deformation of rock or sediment can be used to obtain realistic estimates of frequency and magnitude of postglacial seismic events (Cluff et al., 1980; Hall, 1984). Where this deformation has resulted from tectonic activity, these studies contribute valuable information and allow extrapolation beyond the historical record. However, caution must be exercised in interpreting deformation in glaciated areas, where similar-looking structures can be produced by a variety of mechanisms associated with glaciation (Adams, 1989; Broster, 1989).

Exposures of glacially eroded bedrock with of fset striae and grooves have long been known in and around the city of Saint John, New Brunswick (Fig. 1). When first reported by Matthew (1894), this faulting was attributed to postglacial tectonic deformation of the crust. However, his interpretation was inconclusive and questions concerning the magnitude and origin of the deformation remain unanswered.

Oliver et al. (1970) referred to the Saint John occurrences in their discussion of postglacial faulting in New York and Quebec. They concluded that on a regional basis there was no clear evidence to choose between glacial, tectonic, thermal, hydrological and chemical processes as the prime cause of the faulting. Matthew's work was reviewed by Adams (1981), who again proposed several hypotheses for the origin of this kind of faulting, but later suggested (Adams, 1989) that much of the movement might have occurred in response to crustal flexure resulting from continental deglaciation. However, none of these authors made a re-examination of the Saint John displacements. This paper describes a detailed study and remapping of Matthews' sites undertaken in an attempt to resolve the question of the origin of the faulting, in the light of present understanding of glacitectonics, neotectonics and local seismicity.

\section{Geological Setting}

The physiography of the Saint John area of New Brunswick consists of a series of fault controlled ridges and valleys striking in a northeasterly direction (O'Brien, 1976; Wardle, 1978; McCutcheon, 1981). Drainage is structurally controlled and the ridge and valley topography reflects the competence of the underlying bedrock (Alcock, 1938). The city itself is character- 


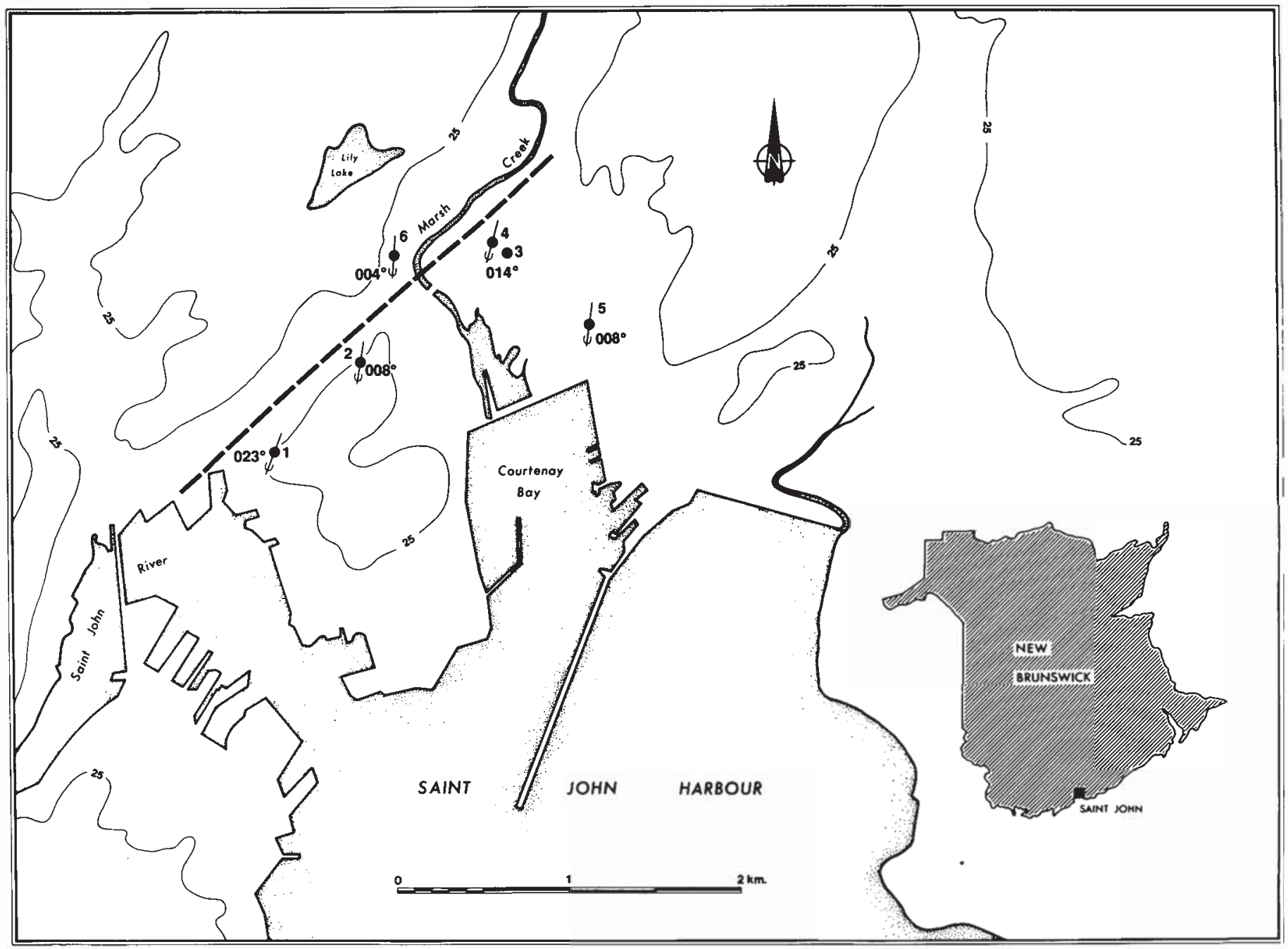

Fig. 1. Location of sites of displaced striae (dots and numbers) with striae directions indicated by direction symbol and average bearing in degrees. The thick broken line indicates the approximate trend of the synclinal axis discussed in the text. Contour $25 \mathrm{~m}$ asl.

ized by a series of high angle reverse or thrust faults (Wardle, 1978; Currie and Nance, 1983), that may be related to horst and graben structures (O'Brien, 1976). Detailed accounts of bedrock stratigraphy are provided by Ruitenberg et al. (1979), Tanoli (1987), Tanoli and Pickerill (1988) and Currie (1985), but need not be reviewed here. A general geological map of the Saint John region is given in Figure 2.

Important to the present study are Cambrian-Early Ordovician strata exposed at several localities throughout the city and referred to as the Saint John Group (Matthew, 1890; Hayes and Howell, 1937; Tanoli, 1987; Tanoli and Pickerill, 1988). These rocks form the major group exposed in the study area and occupy a central location in the city, where they have been folded into a major overturned syncline. The synclinal axis trends northeast along a valley with prominent high ground on the north side and dissected hills and glacially eroded hillocks on the south side (Fig. 1).

The southeastern limb of the syncline is overturned towards the northwest with parallel limbs that dip at $60^{\circ}-70^{\circ}$ to the southeast (Tanoli, 1987). Currie (1985) reported that the northwestern boundary of the Saint John Group is cut by high-angle, southeast-dipping reverse faults of post-Carboniferous age, while the southern boundary of the group is truncated by a prominent thrust fault dipping southward and considered to be Late Carboniferous to Early Permian in age (Rast and Grant, 1973).

Three phases of folding have been recognized in the Saint John Group rocks, the first having produced the major northeasttrending syncline. The two later phases also produced NE(SW) to ENE(WSW) oriented folds (Richards, 1971; Currie et al., 1981; Tanoli, 1987). This deformation is considered to be related to late stages of the pre-Silurian Taconic orogeny, or the Devonian Acadian orogeny (Currie et al., 1981; Nance, 1982; Currie, 1984). Examination of deformation in correlative units away from Saint John, and overlain by undeformed Upper Devonian strata, confirms that the deformation is older than Late Devonian (Brown and Helmstaedt, 1970).

The displaced glacial striae are most evident in argillite and sandstone of the King Square Formation. The unit represents the latest Middle to earliest Upper Cambrian formation of the Saint John Group (Tanoli and Pickerill, 1988) and occupies the core of the syncline (Tanoli, 1987). Deformation of this unit was examined at five sites (Fig. 1), situated on northward facing 


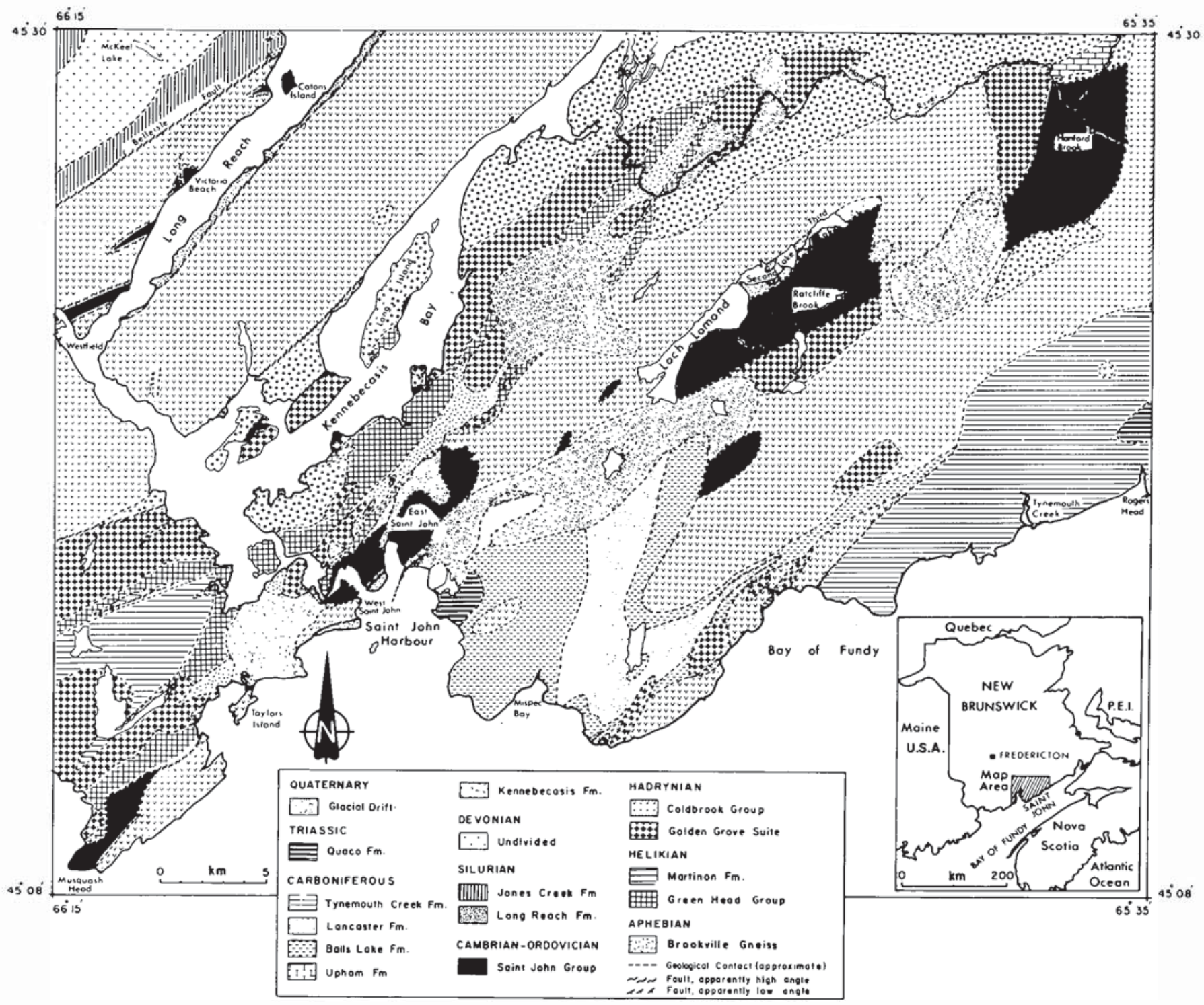

Fig. 2. General geological map of the Saint John region reprinted with permission from Tanoli and Pickerill (1988).

slopes of small bedrock promontories located along the southeastern limb of the syncline. These sites are positioned on the stoss side of hills and were directly exposed to southward directed glacial erosion. A sixth site was examined on the northwest limb of the syncline. All of the outcrops reveal bedrock that has been polished, grooved and striated by glacial action.

The striae were probably formed during Late Wisconsinan time and are representative of the last direction of glacial movement in the area. At this time, active glacial flow was generally southward (Gadd, 1973; Rampton et al., 1984), followed by passive retreat towards the north (Seaman, personal communication, 1989) at around 13,900 B.P. (Rampton et al., 1984, table 2). As ice retreat progressed, sea level rose faster than isostatic rebound, resulting in submergence of the Saint John area (Rampton et al., 1984), that probably contributed to removal of till from much of the area. The displaced striae indicate that the faulting is either postglacial or associated with deglaciation of the area.

\section{Method of investigation}

At sites 1,2 and 5, a grid and survey points were established along the slope, so that measurements could be examined in a profile perpendicular to the strike of the beds. The grids allowed examination of the faults over several metres regardless of discontinuous exposure due to soil and vegetation cover. At sites 3,4 and 6 , only a few scattered displacements were available for measurement.

The largest displacement found along each exposed fracture was chosen for analysis. Vertical offsets and surface distances between fractures were measured along each profile (Tables 1,2, 3). Measurements were taken as accurately as possible using a graduated $\mathrm{mm}$ scale. Dextral throws amounting to a few centimetres were recorded along three of the fractures. 
Table 1. Orientation and offset of fractures at Site No. 1.

(a) Oblique fractures in upper $6 \mathrm{~m}$ of exposure

$\begin{array}{ccc}\text { Bearing } & \text { Bearing } & \text { Bearing } \\ 045 @ 80^{\circ} & 291 @ 76^{\circ} & 210 @ 78^{\circ} \\ 025 @ 78^{\circ} & 020 @ 80^{\circ} & 205 @ 86^{\circ} \\ 079 @ 36^{\circ} & 019 @ 86^{\circ} & 215 @ 76^{\circ} \\ 025 @ 64^{\circ} & 220 @ 80^{\circ} & 011 @ 84^{\circ} \\ 215 @ 76^{\circ} & 023 @ 82^{\circ} & 026 @ 72^{\circ} \\ 296 @ 80^{\circ} & 035 @ 82^{\circ} & 198 @ 80^{\circ} \\ 022 @ 72^{\circ} & 016 @ 80^{\circ} & 198 @ 78^{\circ}\end{array}$

(b) Displaced fractures exposed at section

\section{Distance between fractures $(\mathrm{cm})$}

1. Datum $6 \mathrm{~m}$ below top

2. 250

3. 200

4. 85

5. 100

6. 40

7. 80

8. 25

9. 20

10. 30

11. 40

12. 30

13. 25

14. 45

15. 30

16. 30

17. 50

18. 100

19. 65

20. 25

21. 100

22. 70

23. 70

24. 35

25. 50

26. 40

27. 10

28. 10

29. 15

30. 20

31. 40

32. 42

33. 50

34. 60

35. 25

36. 10

37. 30

38. 20

39. 35
Amount of offset (mm)

20

$-$

1

$-$

3

22

60

60

20

20

21

15

12

50

10

27

-

3

9

5

1

17

$-$

22

3

12

30

10

5

10

33

34

50

30

2

3

3

3

16
Bearing

144 @ 48

$146 @ 20^{\circ}$

$137 @ 58^{\circ}$

$143 @ 68^{\circ}$

$142 @ 32^{\circ}$

$138 @ 42^{\circ}$

$148 @ 42^{\circ}$

$138 @ 80^{\circ}$

$146 @ 28^{\circ}$

148 @ $62^{\circ}$

$142 @ 30^{\circ}$

135 @ 32

$146 @ 28^{\circ}$

$140 @ 45^{\circ}$

$142 @ 68^{\circ}$

$143 @ 37^{\circ}$

$147 @ 40^{\circ}$

$142 @ 42^{\circ}$

$144 @ 48^{\circ}$

$140 @ 39^{\circ}$

$141 @ 33^{\circ}$

$147 @ 50^{\circ}$

$142 @ 48^{\circ}$

$147 @ 42^{\circ}$

$142 @ 35^{\circ}$

$147 @ 34^{\circ}$

$146 @ 48^{\circ}$

$142 @ 40^{\circ}$

$144 @ 39^{\circ}$

$145 @ 37^{\circ}$

$150 @ 35^{\circ}$

$147 @ 40^{\circ}$

$156 @ 48^{\circ}$

$154 @ 41^{\circ}$

$146 @ 38^{\circ}$

$140 @ 36^{\circ}$

$140 @ 38^{\circ}$

$143 @ 38^{\circ}$

$147 @ 45^{\circ}$
Upthrown side

N

$-$

N

-

N

N

N

N

N

N

N

N

N

N

N

N

$-$

N

N

N

N

N

$-$

N

N

S

N

S

N

S

N

N

N

N

N

N

N

N 
Table 2. Orientation and offset of fractures at Site No. 2

\begin{tabular}{|c|c|c|}
\hline & $\begin{array}{l}\text { Distance betwcen } \\
\text { fractures }(\mathrm{cm})\end{array}$ & $\begin{array}{l}\text { Amount of } \\
\text { offset }(\mathrm{mm})\end{array}$ \\
\hline 1. & Datum $m$ bclow top & 4 \\
\hline 2. & 94 & 4 \\
\hline 3. & 104 & 1 \\
\hline 4. & 140 & 4 \\
\hline 5. & so & 20 \\
\hline 6. & 40 & 3 \\
\hline 7. & 20 & 3 \\
\hline 8. & 12 & 3 \\
\hline 9. & 60 & 10 \\
\hline 10. & 100 & 24 \\
\hline 11. & 40 & 2 \\
\hline 12. & 10 & 5 \\
\hline 13. & 40 & 7 \\
\hline 14. & 15 & 7 \\
\hline is. & 15 & 6 \\
\hline 16. & 30 & 7 \\
\hline 17. & 40 & 4 \\
\hline 18. & 25 & 8 \\
\hline 19. & 40 & 8 \\
\hline 20. & 15 & 8 \\
\hline 21. & 25 & 10 \\
\hline 22. & 30 & 7 \\
\hline 23. & 30 & 4 \\
\hline 24. & 10 & 3 \\
\hline 25 . & 15 & 11 \\
\hline 26. & 18 & 14 \\
\hline 27. & 25 & 5 \\
\hline 28. & 20 & 5 \\
\hline 29. & 35 & 10 \\
\hline 30. & so & 18 \\
\hline 31. & 40 & 17 \\
\hline 32. & 17 & 3 \\
\hline 33. & 12 & 4 \\
\hline 34. & 12 & 7 \\
\hline 35. & 30 & 6 \\
\hline 36. & 30 & 5 \\
\hline 37. & 7 & 3 \\
\hline 38. & 16 & 8 \\
\hline 39. & 23 & 5 \\
\hline 40. & 18 & 5 \\
\hline 41. & 22 & 10 \\
\hline 42. & 25 & 7 \\
\hline 43. & 20 & 9 \\
\hline 44. & 40 & 8 \\
\hline 45. & 30 & 9 \\
\hline 46. & 30 & 2 \\
\hline 47. & 15 & 8 \\
\hline 48. & S5 & 2 \\
\hline 49. & 20 & 8 \\
\hline so. & 20 & - \\
\hline s1. & 20 & 2 \\
\hline 52. & 25 & - \\
\hline 53. & 30 & 19 \\
\hline 54. & oblique & 5 \\
\hline 55. & 30 & 6 \\
\hline 56. & 20 & 3 \\
\hline 57. & 20 & 2 \\
\hline 58. & 34 & 2 \\
\hline 59. & 7 & 1 \\
\hline 60. & 20. & 5 \\
\hline 61. & 10 & 19 \\
\hline 62. & 10 & 9 \\
\hline 63. & 20 & 7 \\
\hline 64. & 30 & 4 \\
\hline 65. & 10 & 2 \\
\hline 66. & 30 & 5 \\
\hline 67. & 15 & 8 \\
\hline 68. & 100 & 19 \\
\hline 69. & 10 & - \\
\hline 70. & 30 & 9 \\
\hline 71. & 40 & - \\
\hline 72. & 70 & 54 \\
\hline 73. & 10 & 6 \\
\hline 74. & 20 & 10 \\
\hline 75. & 15 & 14 \\
\hline 76. & 25 & 8 \\
\hline 77. & 15 & - \\
\hline 78. & 15 & 16 \\
\hline 79. & 7 & 12 \\
\hline 80. & 20 & 2 \\
\hline 81. & 25 & 14 \\
\hline 82. & 80 & 39 \\
\hline 83. & 40 & 3 \\
\hline 84. & 7 & 2 \\
\hline 85. & 20 & 21 \\
\hline 86. & 20 & 2 \\
\hline 87. & 25 & 13 \\
\hline 88. & 70 & 3 \\
\hline 89. & 10 & 17 \\
\hline 90. & 25 & 17 \\
\hline 91. & 45 & 5 \\
\hline 92. & 45 & 32 \\
\hline 93. & 65 & 35 \\
\hline 94. & 40 & 15 \\
\hline 95. & oblique & - \\
\hline
\end{tabular}

\section{RESULTS}

The style of deformation was found to be the same at all sites. Fractures offset striae and grooves, forming small reverse faults, most in the order of a few millimetres of displacement (Fig. 3a). The faults are reverse in the sense that the north-facing (upglacier) edge is generally upthrown. Most displacements form a sharp edge along the fracture plane (Fig. 3b), although evidence of glacial erosion is apparent on some displacements (Fig. 3c), indicating that some faulting occurred during or prior to glaciation.

The orientation of the faults is commonly parallel to the northeast strike of bedding (Fig. 4). They are most commonly located at bedding contacts as clean, tight fractures, a few tens of metres long. Dip is similar to that of individual beds, although in some instances the faults dip more steeply. Some displacements were scissor-type and most varied in amount of vertical offset along the fracture. Typically, movement was in the reverse sense, but dextral strike-slip movements with up to $15 \mathrm{~mm}$ of lateral displacement were recognized on 3 of the 185 fractures examined. The very strong northeast orientation of the reverse faults (Fig. 4) implies that they developed in response to compression with $\sigma_{1}$, aligned NW-SE, although another explanation of this orientation may be the pronounced anisotropy of the rocks.

\section{Study Sites}

Sites 1 to 5 were first investigated by Matthew (1894) who reported fractured and displaced bedrock. The best exposed outcrops and offsets occur at sites 1 and 2 (Fig. 1), located on the north side of a $40 \mathrm{~m}$-high hill, which forms the south wall of a valley approximately perpendicular to the direction of glacial movement. The valley is aligned roughly parallel to the synclinal axis mentioned above. Site 1 is located on the southwestern end of the hill and faces northwest. A $29 \mathrm{~m}$ long patch of exposed bedrock was examined along a slope rising from about $10 \mathrm{~m}$ asl at the foot of Sewell Street, to about $25 \mathrm{~m}$ asl just below Carleton Street. At this site, 60 fractures were measured (Table 1). Two $60 \mathrm{~mm}$ offsets were found at this site, representing the largest displacements recorded during this study. The statistical distribution of the displacements are shown in the form of a stem leaf diagram in Table 4, together with a summary of the statistical parameters. Stem leaf diagrams are a form of histogram in which information on the data is retained while simultaneously displaying the grouped information (Tukey, 1977). For example, at site 1 (Table 4) 16 joints and faults were found that showed less than $10 \mathrm{~mm}$ displacement; one of $9 \mathrm{~mm}$, two of $5 \mathrm{~mm}$, six of $3 \mathrm{~mm}$, one of $2 \mathrm{~mm}$, two of $1 \mathrm{~mm}$, and four with no displacement.

The fractures at site 1 can be divided into two subgroups; one with obvious faults parallel to bedding, and a second group of smaller joints, oblique to bedding (Fig. 4a). The second group was found in the top part of the exposure and had diamicton infillings in many of the fractures. Fracture fillings were mainly sand and silt, although small pebbles were also present in the largest filling, approximately $2 \mathrm{~cm}$ wide. The oblique fractures occur at all sections, but were most abundant in the upper part of site 1. 
Table 3. Orientation and offset of fractures at Site No. 5.

\begin{tabular}{|c|c|c|c|c|}
\hline & $\begin{array}{l}\text { Distance between } \\
\text { fractures }(\mathrm{cm})\end{array}$ & $\begin{array}{l}\text { Amount of } \\
\text { offset (mm) }\end{array}$ & Bearing & Upthrown Side \\
\hline 1. & oblique & - & $182 @ 36^{\circ}$ & - \\
\hline 2. & 300 below road & 6 & $134 @ 68^{\circ}$ & $\mathrm{N}$ \\
\hline 3. & oblique & - & $160 @ 30^{\circ}$ & - \\
\hline 4. & oblique & - & $184 @ 36^{\circ}$ & - \\
\hline 5. & 380 & 3 & $125 @ 68^{\circ}$ & $\mathrm{N}$ \\
\hline 6. & 110 & - & $136 @ 61^{\circ}$ & - \\
\hline 7. & oblique & 10 & $185 @ 65^{\circ}$ & $\mathrm{N}$ \\
\hline 8. & 50 & 20 & $130 @ 69^{\circ}$ & $\mathrm{N}$ \\
\hline 9. & 30 & 6 & $134 @ 58^{\circ}$ & $\mathrm{N}$ \\
\hline 10. & 125 & 4 & $128 @ 62^{\circ}$ & $\mathrm{N}$ \\
\hline 11. & 200 & 9 & $138 @ 64^{\circ}$ & $\mathrm{N}$ \\
\hline 12. & 70 & 4 & $126 @ 56^{\circ}$ & $\mathrm{N}$ \\
\hline 13. & 50 & 5 & $125 @ 54^{\circ}$ & $\mathrm{N}$ \\
\hline 14. & 70 & 10 & $132 @ 62^{\circ}$ & $\mathrm{N}$ \\
\hline 15. & 80 & 5 & $128 @ 60^{\circ}$ & $\mathrm{N}$ \\
\hline 16. & 240 & 5 & $128 @ 50^{\circ}$ & $\mathrm{N}$ \\
\hline 17. & 65 & 21 & $136 @ 52^{\circ}$ & $\mathrm{N}$ \\
\hline 18. & 70 & 2 & $128 @ 53^{\circ}$ & $\mathrm{N}$ \\
\hline 19. & 55 & 7 & $128 @ 63^{\circ}$ & $\mathrm{N}$ \\
\hline 20. & 130 & 37 & $136 @ 60^{\circ}$ & $\mathrm{N}$ \\
\hline 21. & 125 & 3 & $136 @ 48^{\circ}$ & $\mathrm{N}$ \\
\hline 22. & 140 & 22 & $136 @ 50^{\circ}$ & $\mathrm{N}$ \\
\hline 23. & 200 & 12 & $136 @ 58^{\circ}$ & $\mathrm{N}$ \\
\hline 24. & 125 & 22 & $133 @ 60^{\circ}$ & $\mathrm{N}$ \\
\hline 25. & 135 & 4 & $135 @ 56^{\circ}$ & $\mathrm{N}$ \\
\hline 26. & 25 & 40 & $130 @ 55^{\circ}$ & $\mathrm{N}$ \\
\hline 27. & 75 & 3 & $135 @ 44^{\circ}$ & $\mathrm{N}$ \\
\hline 28. & 25 & 1 & $138 @ 48^{\circ}$ & $\mathrm{N}$ \\
\hline 29. & 20 & 7 & $136 @ 54^{\circ}$ & $\mathrm{N}$ \\
\hline 30. & 80 & 18 & $135 @ 40^{\circ}$ & $N$ \\
\hline
\end{tabular}

Site 2 is the highest outcrop and exposes the greatest number of offsets studied. The site is located along the same hill as section 1, but at a higher elevation, approximately $800 \mathrm{~m}$ to the northeast (Fig. 1). Along Rock Street, a north-northwest slope rises about $20 \mathrm{~m}$ above a street elevation of around $15 \mathrm{~m}$ asl and sporadically exposes thinly bedded argillite and sandstone over a $50 \mathrm{~m}$-long section up the slope. As many as 95 faults and joints were recorded (Table 2), representing a total displacement of $0.818 \mathrm{~m}$. The individual offsets range from $1 \mathrm{~mm}$ to $54 \mathrm{~mm}$ with a median displacement of $6 \mathrm{~mm}$ (Table 4). Poles to these structures cluster in the northwest quadrant (Fig. 4b).

A bedrock excavation perpendicular to strike was examined further along Rock Street, about $50 \mathrm{~m}$ to the west of the main outcrop. There, steeply dipping fractures could be observed to a depth of several centimetres. The majority of fractures occur along bedding planes, although a few were found within beds. The latter were seen to penetrate the rock until they contacted the lower bedding plane. At the intersection of bedding planes and fractures, dip orientation of the fractures changed to follow the bedding plane. This association of fracture change with depth was also recognized at site 1 , where several small $(20 \mathrm{~cm}$ wide, $10 \mathrm{~cm}$ thick) blocks of sandstone were excavated from two beds. These showed the same change in fault dip and its reorientation along the top of the underlying bed.

A road cut along Delhi Street, approximately $240 \mathrm{~m}$ east of site 2, enabled examination of the layered bedrock comprising the southem limb of the syncline. Approximately 60 measurements taken upward through the section showed a distinct steepening in bedding dip from about $35^{\circ}$ in lowermost exposures around $15 \mathrm{~m}$ asl, to nearly vertical at the top of the hill at around $30 \mathrm{~m}$ asl; delineating a field of values shown in Figure 4c.

Sites 3 and 4 (Fig. 1) are on small hillocks, no more than 4 $\mathrm{m}$ above surrounding terrain. Vegetation and construction have obscured most of the exposures. A few small offsets were examined, but faulting is less extensive than at any of the other sites. Measurements of orientations and displacements were consistent with the deformation at the other sites.

Site 5 is located approximately $150 \mathrm{~m}$ west of the intersection of Bayside Drive and Park Avenue, at the front of a rounded hillock, slightly elongated in a north-south direction and similar 

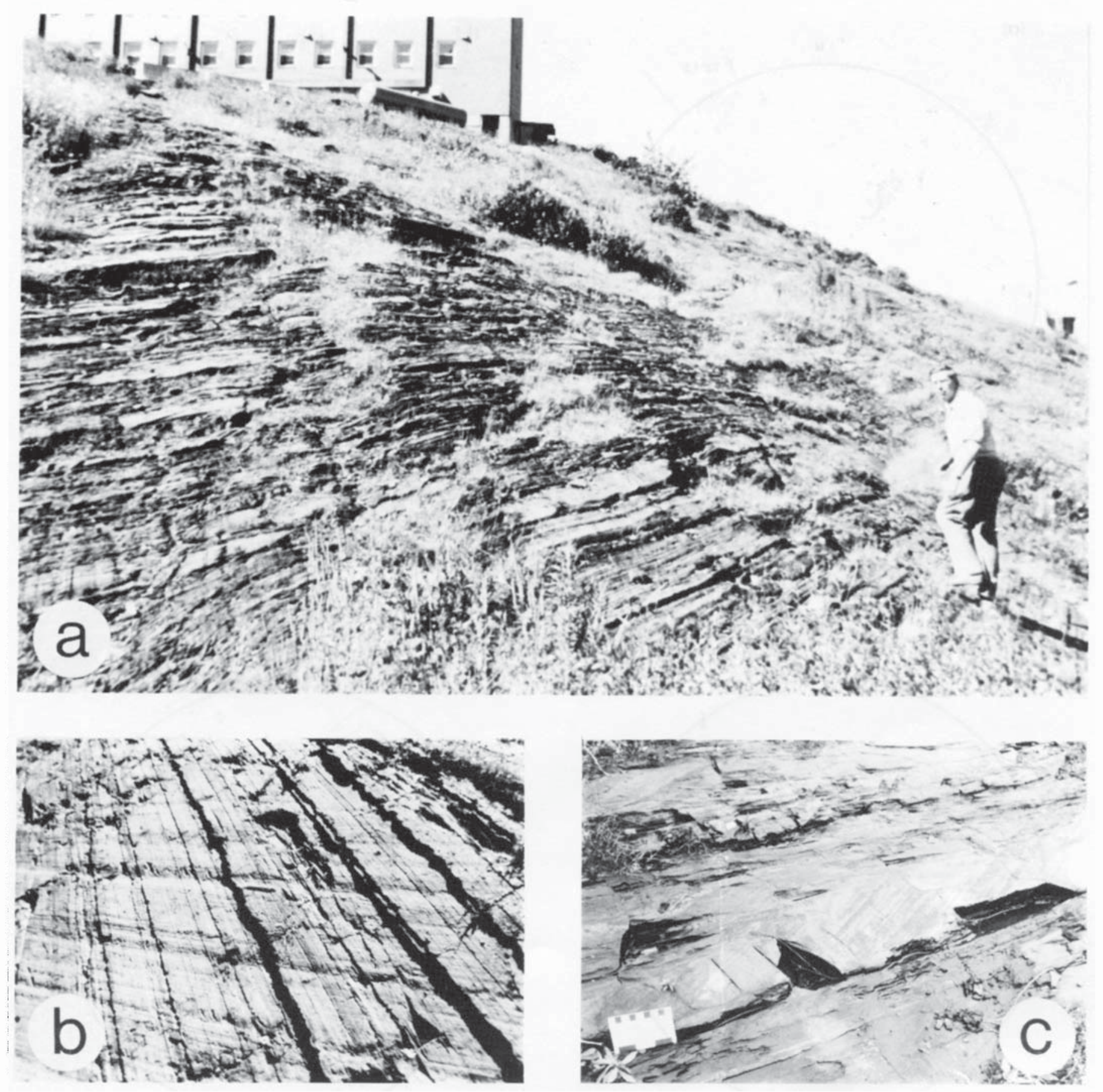

Fig. 3. Outcrop of King Square Formation at Rock Street (a), showing grooves and striae crossing sharp-edged small reverse faults (b) and glacially rounded edges on some layers (c). Glacial movement has been towards the building in a and from left to right in b and c, note pen in centre of photo b.

in appearance to a large subdued whaleback. Bedrock was exposed on the north facing slope. Thirty fractures were measured (Table 3 ) over a $40 \mathrm{~m}$-long exposure of polished and striated argillite and sandstone. The maximum displacement recorded at this site was $40 \mathrm{~mm}$ (Table 4). Fracture orientations are consistent with those recorded at the other sites (Fig. 4c).

Outcrops were also examined along the north side of the valley (Site 6: Fig. 1), approximately $600 \mathrm{~m}$ north of site 2 . Striae directions, ranging from $170^{\circ}-190^{\circ}$, with $184^{\circ}$ being the most common and best preserved, were recorded on polished, finegrained sandstone of the King Square Formation. None of the striae appeared to be displaced. Joints were examined along new road cuts $100 \mathrm{~m}$ west of site 6 (Fig. 1), at the junction of Somerset and Winter streets. These joints are unweathered, concave upward surfaces that dip in the direction $010^{\circ}$ at between $58^{\circ}-74^{\circ}$ (Fig. 5). The shallow depth, dip orientation parallel to the direction of glacial movement, and downward taper of curvilinear joints, are characteristicscommonly associated with a glacitec- 
(a)

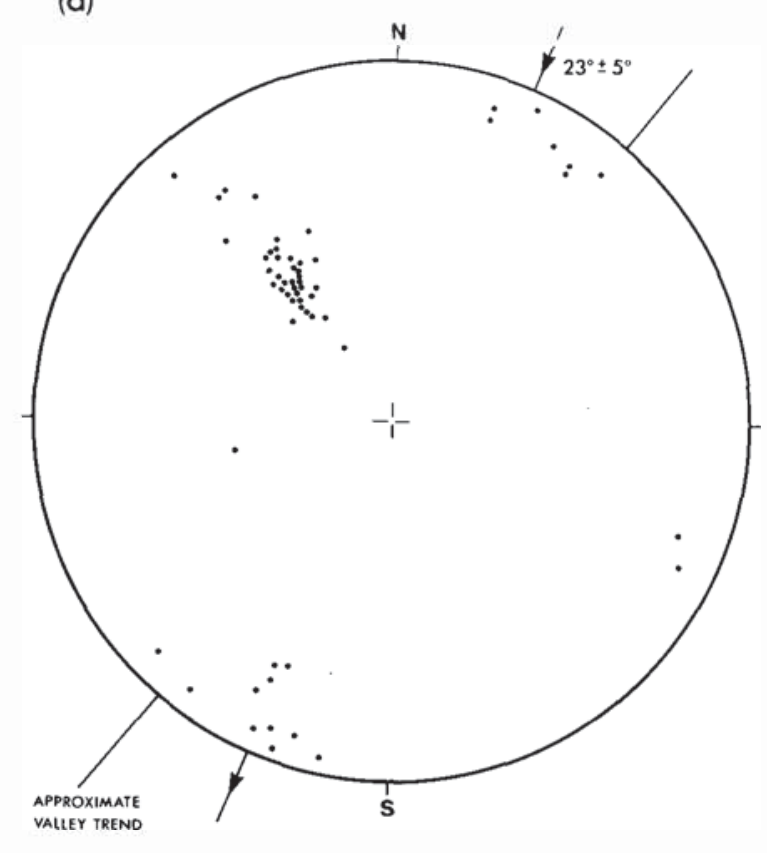

(c)

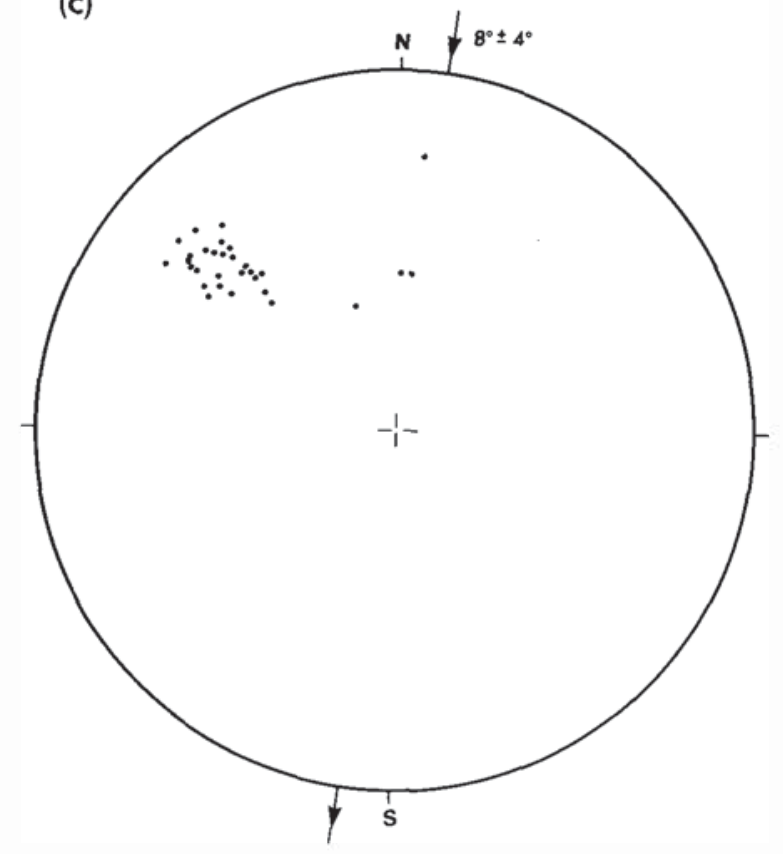

(b)

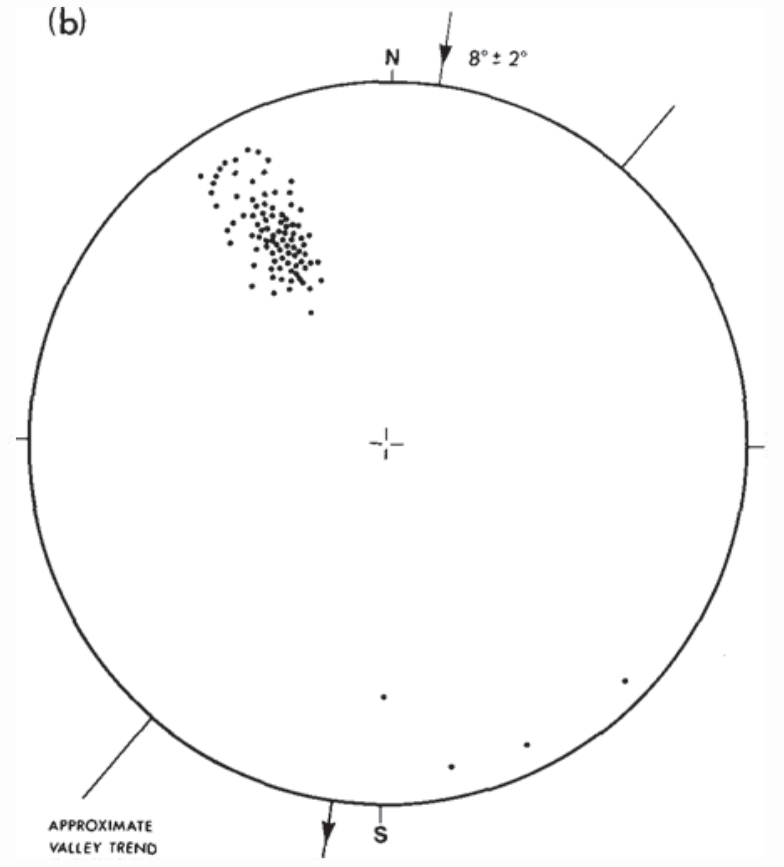

(d)

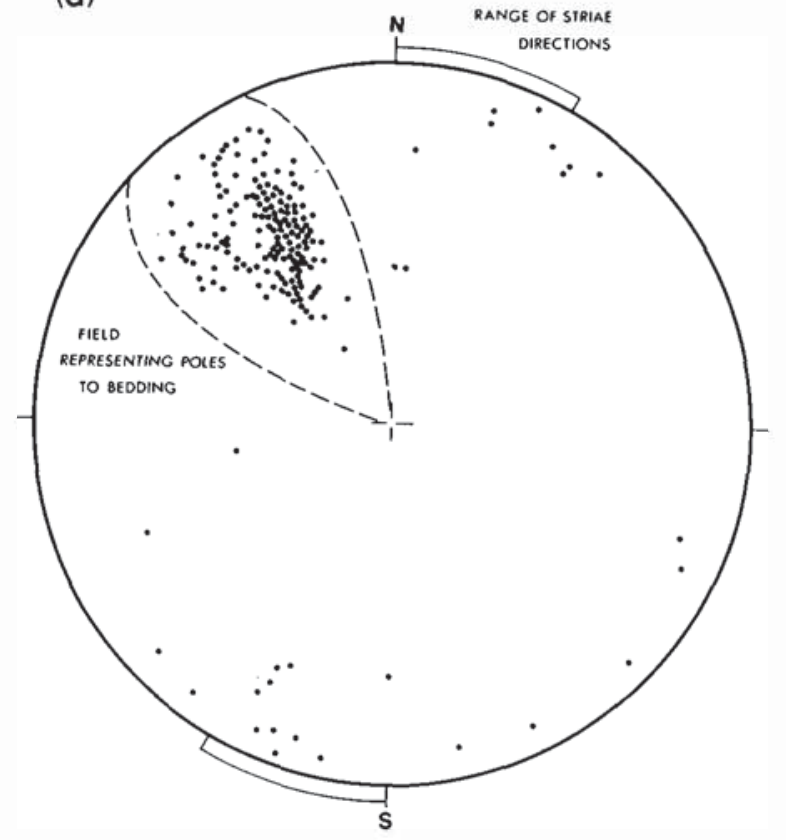

Fig. 4. Poles of faults and joints in King Square Formation at site 1 (a), site 2 (b), site 5 (c), and a composite of all three sites (d), plotted on lower hemisphere. The dirction of glacial movement is indicated by arrows with the average and range of readings given.

tonic origin (Broster et al., 1979; Hicock and Dreimanis, 1985; Broster and Clague, 1987; Broster, 1989).

\section{DISCUSSION}

Matthew (1894) suggested that the displaced striae could be attributed to one of two causes; (a) sinking of crustal material beneath the valley or (b) stress from the southeast, but milder than that responsible for forming the syncline and thrust faulting along the valley. He favoured the latter cause and did not consider a glacial origin. We believe that these two possible origins, tectonic or glacigenic, need to be re-examined in the light of contemporary studies on glacial isostasy, glacitectonics and an increased data base on regional seismicity. 
Table 4. Frequency distribution and statistical parameters at sites 1,2 and 5.

Site 1. Stem Leaf Diagram

\begin{tabular}{|c|c|c|c|c|}
\hline Stem & Leaf & $\#$ & & \\
\hline $\begin{array}{l}6 \\
5\end{array}$ & 00 & 2 & $\begin{array}{l}N=39 \\
\text { Max offset }\end{array}$ & 60 \\
\hline 5 & 00 & 2 & $\begin{array}{l}\text { Max orfset } \\
\text { Mean Displacement }\end{array}$ & $\begin{array}{l}60 \\
16.5\end{array}$ \\
\hline 4 & & & Standard Deviation & 16.7 \\
\hline 4 & & & $75 \%$ Quartile & 22 \\
\hline 3 & & & Median & 12 \\
\hline 3 & 0034 & 4 & $25 \%$ Quartile & 3 \\
\hline 2 & 7 & 1 & & \\
\hline 2 & 000122 & 6 & $\Sigma$ of Displacement & 642 \\
\hline 1 & 567 & 3 & & \\
\hline 1 & 00022 & 5 & & \\
\hline 0 & 559 & 3 & & \\
\hline 0 & 0000112333333 & 13 & & \\
\hline
\end{tabular}

Site 2. Stem Leaf Diagram

\begin{tabular}{|c|c|c|c|c|c|}
\hline Stem & Leaf & $\#$ & & & \\
\hline 5 & 4 & 1 & $N=87$ & & \\
\hline 4 & & & Max offset & 54 & $\mathrm{~mm}$ \\
\hline 4 & & & Mean Displacement & 8.6 & m \\
\hline 3 & 59 & 2 & Standard Deviation & 8.8 & $\mathrm{~mm}$ \\
\hline 3 & 2 & 1 & $75 \%$ Quartile & 10 & $\mathrm{~m}$ \\
\hline 2 & & & Median & 6 & \\
\hline 2 & 014 & 3 & $25 \%$ Quartile & 3 & $\mathrm{~mm}$ \\
\hline 1 & 567778999 & 9 & & & \\
\hline 1 & 022 & 3 & $\sum$ of Displacement & 818 & \\
\hline 0 & 5555555555666677777778888888889999 & 34 & & & \\
\hline 0 & 0000001122222222223333333334444444 & 34 & & & \\
\hline
\end{tabular}

Site 5. Stem Leaf Diagram

\begin{tabular}{|c|c|c|c|c|c|}
\hline Stem & Leaf & \# & & & \\
\hline 4 & 0 & 1 & $\mathrm{~N}=30$ & & \\
\hline 3 & 7 & 1 & Max offset & 40 & $\mathrm{~mm}$ \\
\hline 3 & & & Mean Displacement & 9.7 & $\mathrm{~mm}$ \\
\hline 2 & & & Standard Deviation & 10.3 & $\mathrm{~mm}$ \\
\hline 2 & 0122 & 4 & $75 \%$ Quartile & 13.5 & $\mathrm{~mm}$ \\
\hline 1 & 8 & 1 & Median & 5.5 & $\mathrm{~mm}$ \\
\hline 1 & 002 & 3 & 25\% Quartile & 3 & $\mathrm{~mm}$ \\
\hline 0 & 55566779 & 8 & & & \\
\hline 0 & 000012333444 & 12 & $\sum$ of Displacement & 291 & $\mathrm{~mm}$ \\
\hline
\end{tabular}

\section{Tectonic origin}

Displacement of the glacial striae and grooves has resulted from minor faulting produced by shear concentrated at the bed contacts. The reverse faulting and layer-parallel movement implies compression directed towards the northwest. Such a direction is perpendicular to the synclinal axis and is in agree- ment with the direction of compression attributed to the formation of high angle, southeast-dipping, reverse faults of postCarboniferous age, that truncate the northwestern side of the Saint John Group (Currie, 1985). However, the faults have occurred along existing planes of weakness and it is possible that their orientation is not a true indication of stress direction.

If the faults are to be associated with the present day tectonic 


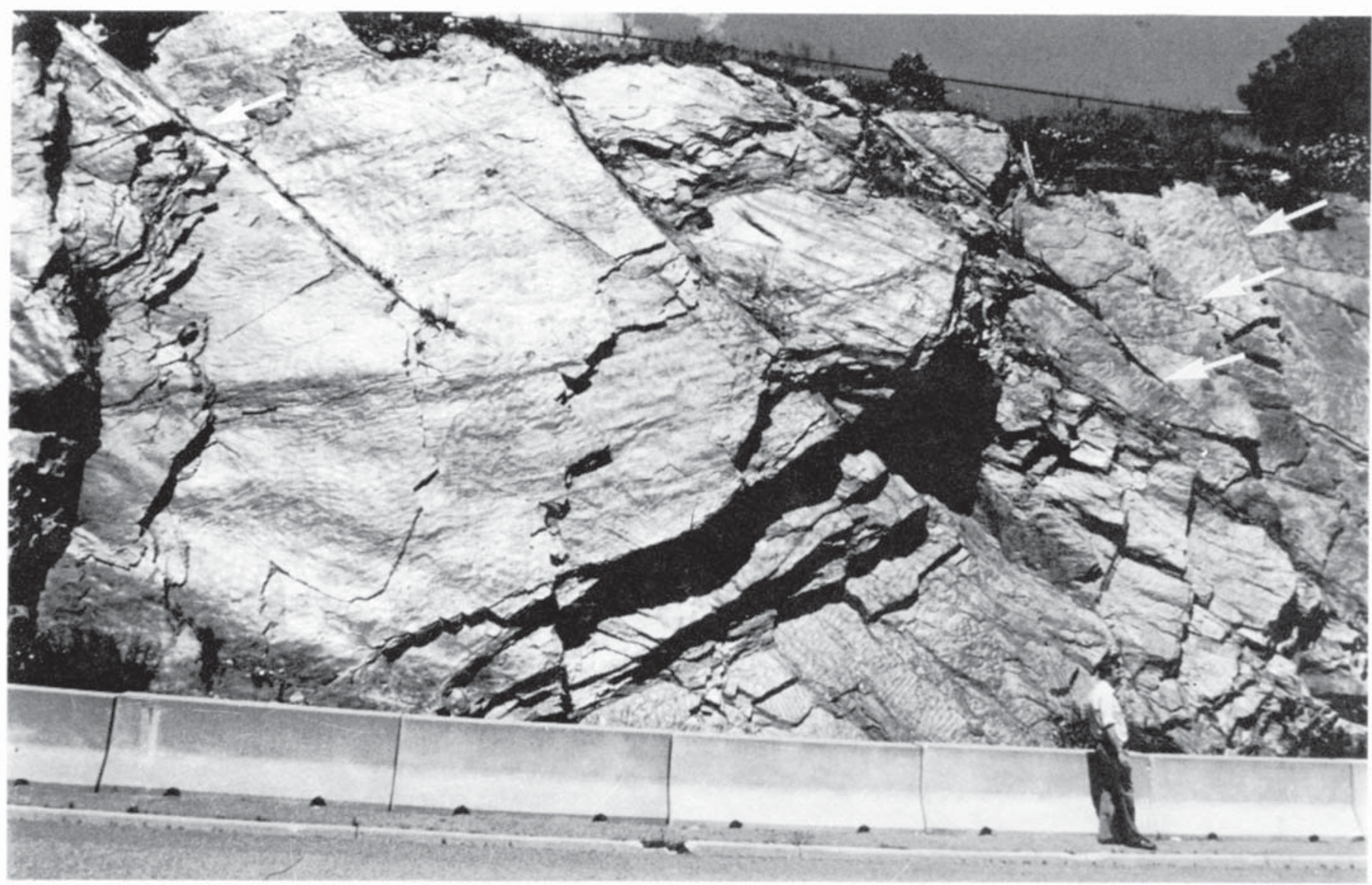

Fig. 5. Road cut oriented approximately southwest-northeast along north side of valley showing shallow upward-curving glacitectonic fractures (arrows). Glacial movement was oblique to the photograph, approximately right to left.

regime, we might expect to find a correlation between the displacements and contemporary seismicity. The relationship between the amount of displacement and the size of an earthquake is therefore of interest. Bonilla (1988) showed that surface displacements ranging from a few millimetres to several decimeters have been usually associated with earthquakes having magnitudes between 5.0 and 6.0. However, most of the reported faults had surface lengths in the order of kilometres, rather than the tens of metres for faults of the present study. One exception was an event that occurred in a diatomite quarry near to Lompoc, California (Yerkes et al., 1983). A $575 \mathrm{~m}$-long rupture zone formed in an interbedded sequence of clay, diatomite and diatomaceous shale on the north limb of an open symmetrical syncline and gave rise to a $\mathrm{M}_{\mathrm{L}} 2.5$ earthquake. A reverse right oblique surface fracture with a maximum net slip of $25 \mathrm{~cm}$ was mapped at this site. The maximum reverse dip slip movement was $23 \mathrm{~cm}$. This shallow bedding plane rupture event was believed to have been triggered by crustal unloading in the presence of regional north-south compression.

The wide range of displacements and the lack of statistical significance at the $95 \%$ confidence level for the regression of magnitude against displacement, in Bonilla's (1988) study, makes it difficult to deduce the magnitudes of implied earthquakes associated with the offsets at the Saint John sites. Matthew (1894) concluded that offsets at Rock Street (Site 2), totalled 1.72 $\mathrm{m}$ of displacement. Our own measurements show that displacements occurring in the upper part of the slope above Rock Street could be summed to $0.818 \mathrm{~m}$. Nonetheless, we feel that such an assessment may be misleading, especially if this total amount of displacement were taken to be the product of a single seismic event. However, if displacements of up to $60 \mathrm{~mm}$ are still taking place, then earthquakes in the lower end of the magnitude range might possibly occur at these locations.

Table 5 shows a summary of earthquakes that have been reported in the Saint John region and assessed by Burke and Gerd'son (1988). The compilation is based on catalog listings and scanning of New Brunswick newspapers published during the last two centuries. From press accounts and reaction to instrumentally recorded earthquakes in the Saint John region in the 1970's, the threshold of felt and reported earthquakes is estimated to be between magnitudes of 3 and 3.5. It is therefore believed to be a complete record for earthquakes with magnitudes greater than 3.5 .

Epicentres of historically recorded earthquakes are too uncertain to associate with a particular place or group of rocks in Saint John. Although the reported epicentres of the June 1, 1956 earthquakes lie close to outcrops of the Saint John Group at Reversing Falls on the edge of the city, this is probably because the only report of these events were from employees of Irving Pulp and Paper Plant at that location and no determination of the 
Table 5. List of earthquakes in Saint John Area.

\begin{tabular}{|c|c|c|c|c|c|}
\hline Date & $\frac{\text { Time }}{\text { (U.T.) }}$ & \multicolumn{2}{|c|}{$\frac{\text { Location }}{\left({ }^{\circ} \mathrm{N},{ }^{\circ} \mathrm{W}\right)}$} & Magnitude & Comments \\
\hline 1764 Sept. 30 & $16: 00$ & & & 4.4 & $\begin{array}{l}\text { Event reported as being felt in } \\
\text { Saint John. Location uncertain. }\end{array}$ \\
\hline 1838 Dec. 12 & 01:00 & 45.4 & 66.2 & 3.0 & $\begin{array}{l}\text { Small local earthquake in } \\
\text { Westfield-Greenwich area. }\end{array}$ \\
\hline 1869 Jan. 16 & $06: 15$ & 45.3 & 66.1 & 3.0 & $\begin{array}{l}\text { Small local earthquake felt } \\
\text { only in Saint John. }\end{array}$ \\
\hline 1888 Mar. 26 & $10: 30$ & 45.3 & 66.1 & 3.0 & $\begin{array}{l}\text { Local earthquake reported felt } \\
\text { in north part of Saint John. }\end{array}$ \\
\hline 1898 Aug. 14 & 07:00-? & 45.5 & 66.1 & 3.1 & $\begin{array}{l}\text { Earthquake felt at points } \\
\text { ranging from Hamstead to } \\
\text { Westfield to Torryburn Point. }\end{array}$ \\
\hline 1909 April 14 & $10: 20$ & 45.4 & 66.4 & 3.0 & $\begin{array}{l}\text { Small local earthquake felt at } \\
\text { Westfield and Welsford. }\end{array}$ \\
\hline 1956 June 1 & $10: 30$ & 45.27 & 66.05 & 1.7 & $\begin{array}{l}\text { Small local events reported } \\
\text { felt at Reversing Falls in Saint }\end{array}$ \\
\hline & $11: 40$ & 45.27 & 66.05 & 1.9 & $\begin{array}{l}\text { John but not recorded or } \\
\text { reported felt by local press. }\end{array}$ \\
\hline 1975 Oct. 13 & 09:17:49 & 45.09 & 65.92 & 2.7 & $\begin{array}{l}\text { Small local earthquake. } \\
\text { Not reported felt in New } \\
\text { Brunswick newspapers. }\end{array}$ \\
\hline 1975 Oct. 15 & $03: 26: 17$ & 45.11 & 65.89 & 3.1 & $\begin{array}{l}\text { Small local earthquake. } \\
\text { Felt in Saint John. }\end{array}$ \\
\hline 1977 Dec. 26 & $16: 19: 52$ & 44.96 & 66.70 & 0.6 & $\begin{array}{l}\text { Not reported felt in New } \\
\text { Brunswick newspapers. }\end{array}$ \\
\hline 1979 April 20 & $10: 32: 49$ & 45.18 & 66.00 & 2.8 & $\begin{array}{l}\text { Small local earthquake. } \\
\text { Felt in Saint John. }\end{array}$ \\
\hline 1986 Jan. 24 & $20: 26: 50$ & 45.34 & 66.26 & 1.6 & $\begin{array}{l}\text { Reported in National } \\
\text { Summary for Jan. - Mar., } 1987 .\end{array}$ \\
\hline
\end{tabular}

epicentre was made from seismograph records. None of the epicentres of instrumentally determined earthquakes plot within the mapped area of the Saint John Group rocks, most of them being to the south, offshore in the Bay of Fundy. Thus, there is no direct evidence of any contemporary seismicity being associated with the of fset glacial striae.

One indirect association of ground movement with the Saint John Group is afforded by the displacement of part of a building during a large regional earthquake in 1869. An article in the October 22, 1869 issue of the Daily Telegraph reports minor structural damage to a dwelling on Union Street, near Charlotte Street. The article states "the building is built of wood and rests on an earth foundation. It seems that the rock support of the wall of the rear extension was greatly disturbed by the shock and has sunk about a foot, leaving the wall unsupported, for a distance of five or six feet." Roe and Colby (1875) plot the location of the house within the mapped area of the Saint John Group and the movement induced by the earthquake may reflect displacement along one or more of the slippage planes, although settlement of the sediment foundation is another possibility.

A review of deep overcoring measurements and fault plane solutions from earthquakes located in eastern Canada indicates a generally northeast direction for maximum horizontal stress (Lambert and Vanicek, 1979; Yang and Aggarwal, 1981; Hasegawa et al., 1985; Plumb and Cox, 1987; Adams, 1989). Analyses of borehole elongation data by Plumb and Cox (1987) confirms this trend and suggests that minimum stress directions are orthogonal, one horizontal trending NW-SE, with the least 
principal stress direction towards the vertical. Their closest stress measurement to Saint John was at Bloomfield $\left(45.99^{\circ} \mathrm{N}, 65.78^{\circ} \mathrm{W}\right)$, about $60 \mathrm{~km}$ to the northeast, where the principal stress direction was $\mathrm{N} 66^{\circ} \mathrm{E}$. The reverse faulting at Saint John implies compression oriented NW-SE (Fig. 4d) perpendicular to the direction of maximum horizontal stress (NE-SW). This suggests an origin by other mechanisms.

\section{Glacigenic}

The term 'glacigenic deformation' is used to signify deformation in association with glacial activity. Such deformation may be the result of dynamic processes (glacitectonic) due to stresses applied or relaxed during glacial activity (Broster, 1989), or static processes such as penecontemporaneous deformation in unconsolidated sediments (Broster and Clague, 1987). Deformation resulting from isostatic adjustments of the crust might also be considered as examples of dynamic glacigenic deformation but they are not commonly considered as glacitectonic (sensu stricto).

The dynamics of glacial processes do not preclude the possibility of ground rupture occurring sometime after glacial ice has retreated from the area. This is thought to be the case for isostatic adjustment of the crust during loading and unloading as a result of glacier growth and decay. For example, Mörner (1978) examined postglacial faults in Sweden and interpreted them to have been co-seismic and formed at the time of the maximum rate of isostatic uplift.

Flint (1971) discussed isostatic adjustment and suggested that during glacier loading the crust subsides in a basinlike fashion and underlying mantle material is transferred outward, away from the basined area, in compensation for the applied load. Subcrustal flow of material may not occur where glacial loading can be accommodated by elastic deformation of the lithosphere. In either case, recovery to near-normal conditions occurs sometime after ice retreat, but with a lag time that may represent thousands of years for non-elastic recovery.

Walcout (1970) proposed that isostatic depression is accompanied by a forebulge, in the order of a few tens of metres high, occurring along the glacial margin as a result of elastic upward bending of the lithosphere. In Walcott's model, isostatic flexural stresses can occur at the edge of an advancing glacier that vary from highly compressional under the ice front, to tensional in the forebulge area. Adams (1989) has applied Walcott's model to regional stress conditions for the Canadian Shield. His calculations suggest that horizontal stresses in the order of $10-20 \mathrm{MPa}$ compression may have existed along the margin of continental ice sheets that were $2 \mathrm{~km}$ thick. Adams (1989) argued that the values of southward (isostatic) flexural stresses can be added to the regional ENE (tectonic) near-surface stresses. These calculations enable joint orientation to be predicted, relative to the superimposed stresses near the end of glaciation of the area. In New Brunswick, the glacigenic and tectonic stress directions were similar to those for the Canadian Shield, although magnitudes were less. Adams' hypothesis predicts that for points very close to the glacial margin, where $\sigma_{1}$ became NE-SW because of the added flexural compression, thrust faults could form, striking NW-SE, approximately parallel to the ice margin.

Our data do not agree with the predicted orientation. One explanation may be that the forebulge extension was negligible at Saint John considering that the advancing glacier may have been only half as thick as estimates used by Walcott (1970) and Adams (1989). Therefore, we believe that displacements by postglacial relief of glacitectonic stress was probably of greater consequence to the formation of the faults than was the effects of isostatic readjustment.

Faults, marked by sharp edges where they intersect the bedrock surface (Fig. 3b), are apparently postglacial, whereas those with rounded edges (Fig. 3c) were likely contemporaneous with glaciation. Glacitectonic (dynamic) deformation is produced in underlying material as a consequence of stress, applied or relaxed, during glacial activity (Broster, 1989). Several other processes can be involved (Broster, 1989) but all are considered to occur within a few tens of metres below the sole of the glacier or proximal to the glacial margin.

Glacial overriding results initially in loading and nearvertical compression of the underlying substrate (Fig. 6). Some recovery from applied stress is achieved with removal of glacial ice, although response would not be purely elastic. Rapid glacial unloading of stressed material can involve vertical extension (Fig. 6), a rapid decrease in strength, and onset of brittle or ductile deformation. Where ice retreat and surface unloading are gradual, or where properties of the substrate are favourable, some units could retain residual stresses for sometime after the glacier has retreated from the area. This near-surface relief from glacitectonic stress is envisaged to be different from crustal flexure caused by isostatic rebound, although in both cases deformation of underlying materials could occur after glaciation.

Glacitectonic stress relief should be similar to other processes of crustal uplift which lead to joint formation by tensile fracture. In horizontal beds, jointing would be expected to be oriented perpendicular to bedding (Suppe, 1985), but in steeply dipping multilayered rocks it would seem reasonable to have displacement occurring along bedding or layer parallel cleavage. Fractures induced by glacial movement commonly strike perpendicular to the direction of glacial flow and dip in a downglacier direction (Broster et al., 1979; Broster and Clague, 1987; Broster, 1989). The orientation of either dynamic glacigenic rupture or fracture caused by residual stresses would likely have been influenced by the orientation of the slaty nature of the bedding. At Saint John, glacial movement was southward oblique to the direction of layering and most fracturing has occurred parallel to bedding (Fig. 4d).

The offsets may be less numerous at some sites because of differences in relief and orientation of the outcrops relative to glacial erosion, loading and unloading. The outcrops at sites 3, 4 , and 5 are topographically lower and more streamlined than sites 1 and 2. Streamlined bedforms are generally associated with areas of high velocity and reduced friction at the glacier sole (Sugden and John, 1976). Prominent eminences tens of metres high would have presented greater obstacles to glacial movement than smaller hillocks. Eminences would represent regions of high friction and pressure during glaciation and would likely have experienced greater stresses than more streamlined bedforms. 


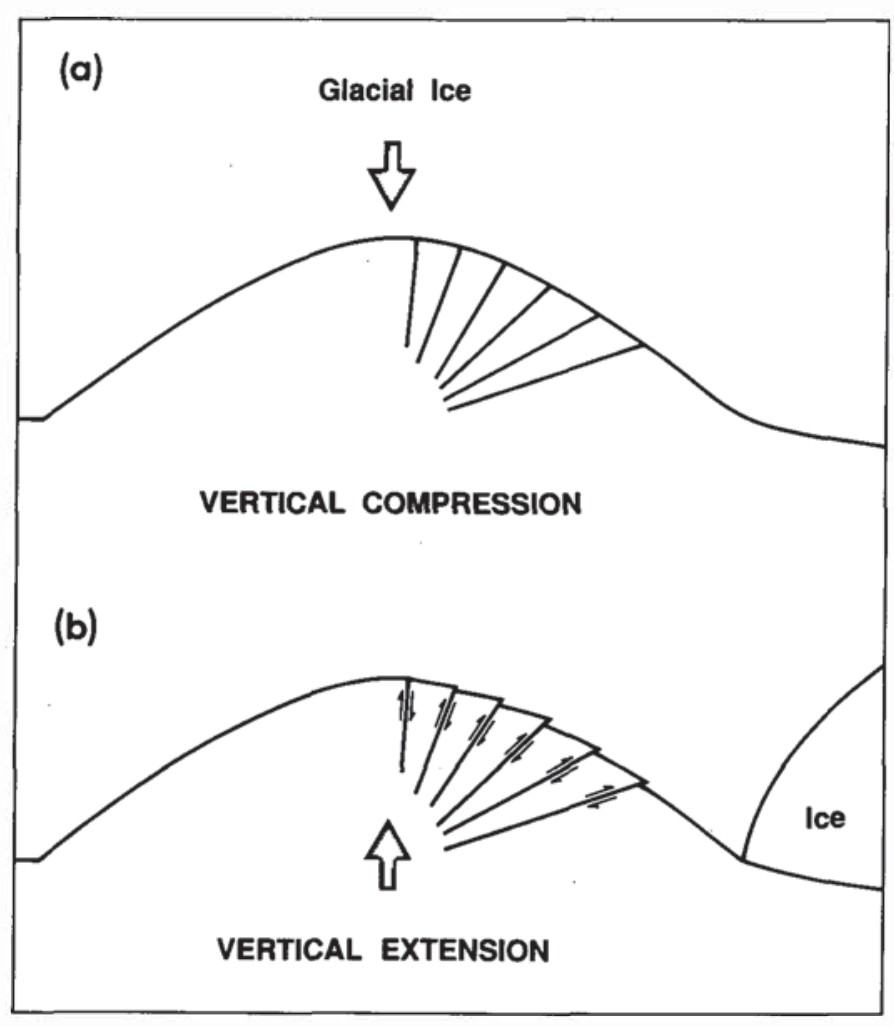

Fig. 6. A schematic drawing illustrating the change in stress to hills during glacial advance (a) and after glacial retreat (b), resulting in small reverse faults due to vertical extension of near-surface bedrock and displacement along steeply dipping layers subparallel to the direction of glacial movement.

We propose a glacitectonic model (Fig. 6) to account for the reverse faulting at Saint John. Glacitectonic fracturing was produced by vertical compression due to initial glacial overriding, and some faulting occurred immediately. Faulting was mainly confined to hills comprising slaty bedrock units with steeply dipping layers. Near-surface fractures and displacements were concentrated along bedding planes which represent the weakest component of the rocks in the area. After ice removal, several of the units experienced vertical extension, thereby facilitating displacement along bedding planes; particularly those bedding planes with dip direction sub-parallel to the direction of extension (Fig. 6). According to this model, fracture was initiated by glacitectonics, but vertical displacement continued after deglaciation. The orientation of bedding as well as vertical unloading and possible pinning of the toe of up-glacier slopes during ice retreat (Fig. 6), are conditions that could have contributed to reverse faulting at Saint John. Minor horizontal (dextral) displacements observed along some of the fractures may be related to regional stress conditions, aberrations in the bedrock, or a slight westward component in the direction of glacial flow.

\section{CONCLUSION}

From the above, we conclude that the small faults are probably due to glacigenic causes rather than tectonic forces. The displacements represent the response of anisotropic multi- layered sedimentary rocks to differential rates of glacitectonic loading and unloading. Glaciation of the area may also have acted as a triggering mechanism, releasing tectonic stresses residing within the unit. Some small degree of movement may still occur in these rocks, although most of the displacements likely occurred very soon after deglaciation of the area.

This interpretation does not preclude the occurrence of other structures related to seismic activity or the likelihood of faults with small displacements forming from tectonic forces from time to time. Grant (in press) has described a $15 \mathrm{~m}$ offset of a glacial shoreline by the Aspy Fault on Cape Breton Island, and the occurrence and timing of this event may have implication to future studies in New Brunswick. The importance of the present study is to draw attention to possible glacigenic origins for similar structures; even though they may appear to have been formed after glacial retreat.

\section{ACKNOWLEDGEMENTS}

We wish to thank Dr. R.K. Pickerill for supplying the figure showing the local geology. John Adams, Stephen Hicock and Joe Wallach are thanked for their review of an earlier manuscript and their helpful comments. Typographical and graphical assistance provided by Angel Gomez and Diane Tabor is gratefully acknowledged. Research funding was received from National Research Council of Canada grant A1886 to Broster.

ADAMS, J. 1981. Postglacial faulting: a literature survey of occurrences in eastern Canada and comparable glaciated areas. Atomic Energy of Canada Limited, Pinawa, Manitoba, Technical Report TR-142, 63 p.

1989. Postglacial faulting in eastem Canada: nature, origin and seismic hazard implication. Tectonophysics, 163, pp. 323-331.

ALCOCK, F.J. 1938. Geology of Saint John region, New Brunswick. Geological Survey of Canada, Memoir 216, 65 p.

BONILLA, M.G. 1988. Minimum earthquake magnitude associated with coseismic surface faulting. Bulletin of Association of Engineering Geologists, 25, pp. 17-29.

BROSTER, B.E. 1989. Glacigenic deformation structures in rock and sediment. Geological Association of Canada, Programs with Abstracts, 14, p. A129.

BROSTER, B.E. and CLAGUE, J.J. 1987. Advance and retreat glacigenic deformation at Williams Lake, British Columbia. Canadian Journal of Earth Sciences, 24, pp. 1421 -1430.

BROSTER, B.E., DREIMANIS, A., and WHTTE, J.C. 1979. A sequence of glacial deformation, erosion and deposition at the icerock interface during the last glaciation; Cranbrook, British Columbia, Canada. Joumal of Glaciology, 23, pp. 283-295.

BROWN, R.L. and HELMSTAEDT, H. 1970. Deformation history in part of the Lubec-Belleisle zone of southem New Brunswick. Canadian Journal of Earth Sciences, 7, pp. 748-767.

BURKE, K.B.S. and GERD'SON, A. 1988. Historical earthquakes in the Saint John Region of New Brunswick. Department of Supply and Services Contract Report 23233-7-3720/01-SZ, Geophysical Division, Geological Survey of Canada, 64 p.

CLUFF, L.S., PATWARDHAN, A.S., and COPPERSMITH, K.J. 1980. Estimating the probability of occurrences of surface faulting earthquakes on the Wasatch Fault Zone, Utah. Bulletin of the Seismological Society of America, 70, pp. 1463-1478. 
CURRIE, K.L. 1984. A reconsideration of some geological relationships near Saint John, New Brunswick. Current Research, Part A, Geological Survey of Canada, Paper 84-1A, pp. 29-36.

- 1985. The geology of Saint John, New Brunswick. In Field excursions, volume 1. Edited by R.K. Pickerill, C.K. Mawer and L.R. Fyffe. Geological Association of Canada/Mineralogical Association of Canada, Joint Annual Meeting, Fredericton, pp. 115-125.

CURRIE, C.K. and NANCE, R.D. 1983. A reconsideration of the Carboniferous rocks of Saint John, New Brunswick. Current Research, Part A, Geological Survey of Canada, Paper 83-1A, pp. 29-36.

CURRIE, C.K., NANCE, R.D., PAJARI, G.E., and PICKERILL, R.K. 1981. Some aspects of the pre-Carboniferous geology of Saint John, New Brunswick. Current Research, Part A, Geological Survey of Canada, Paper 81-1A, pp. 23-30.

FLINT, R.F. 1971. Glacial and Quaternary Geology. John Wiley and Sons, Incorporated, New York, 892 p.

GADD, N.R. 1973. Quatemary geology of southwest New Brunswick, with particular reference to Fredericton area. Geological Survey of Canada, Paper 71-34, 31 p.

GRANT, D.R. In press. Late Quaternary movement of the Aspy Fault, Nova Scotia. Submitted to Canadian Journal of Earth Sciences.

HALL, N.T. 1984. Holocene history of the San Andreas Fault between Crystal Springs Reservoir and San Andreas Dam, San Mateo County, California. Bulletin of the Seismological Society of America, 74, pp. 281-299.

HASEGAWA, H.S., ADAMS, J., and YAMAKAZAKI, K. 1985. Upper crustal stresses and vertical stress migration in eastern Canada. Journal of Geophysical Research, 90, pp. 3637-3648.

HAYES, A.O. and HOWELL, B.F. 1937. Geology of Saint John, New Brunswick. Geological Society of America, Special Paper 5, 146 p.

HICOCK, S.R. and DREIMANIS, A. 1985. Glaciotectonic structures as useful ice-movement indicators in glacial deposits: four Canadian case studies. Canadian Journal of Earth Sciences, 22, pp. 339346.

LAMBERT, A. and VANICEK, P. 1979. Contemporary crustal movements in Canada. Canadian Journal of Earth Sciences, 16, pp. 647-668.

MATTHEW, G.F. 1890 . Illustrations of the fauna of the Saint John Group. Transactions of the Royal Society, Number 5, Volume 8, Section 4, pp. 123-166.

- 1894. Movements of the Earth's crust at Saint John, New Brunswick in post-glacial times. Bulletin of the Natural History Society of New Brunswick, 12, pp. 34-42.

McCUTCHEON, S.R. 1981. Revised stratigraphy of the Long Reach area, southern New Brunswick: evidence for major, northwestward-directed Acadian thrusting. Canadian Journal of Earth Sciences, 18, pp. 646-656.

MORNER, N.-A. 1978. Faulting, fracturing and seismicity as functions of glacio-isostacy in Fennoscandia. Geology, 6, pp. 41-45.

NANCE, D. 1982. Structural reconnaissance of the Green Head Group, Saint John, New Brunswick. Current Research, Part A, Geological
Survey of Canada, Paper 82-1A, pp. 37-43.

O'BRIEN, B.H. 1976. The geology of parts of the Coldbrook Group, southem New Brunswick. Unpublished M.Sc. thesis, University of New Brunswick, 214 p.

OLIVER, J., JOHNSON, T., and DORMAN, J. 1970. Postglacial faulting and seismicity in New York and Quebec. Canadian Journal of Earth Sciences, 7, pp. 579-590.

PLUMB, R.A. and COX, J.W. 1987. Stress directions in eastem North America determined to $4.5 \mathrm{~km}$ from borehole elongation measurements. Joumal of Geophysical Research, 92, pp. 4805-4816.

RAMPTON, V.N., GAUTHIER, R.C., THIBAULT, J., and SEAMAN, A.A. 1984. Quatemary geology of New Brunswick. Geological Survey of Canada, Memoir 416, 77 p.

RAST, N. and GRANT, R.H. 1973. Transatlantic correlation of the Variscan-Appalachian orogeny. American Joumal of Science, 273, pp. 572-579.

RICHARDS, N.A. 1971. Structure in the Precambrian and Paleozoic rocks at Saint John, New Brunswick. Unpublished M.Sc. thesis, Carleton University, 73 p.

ROE, F.B. and COLBY, N.G. 1875. Atlas of Saint John, City and County, New Brunswick. Mika Publishing, Belleville, Ontario, 85 p.

RUTTENBERG, A.A., GILES, P.S., VENUGOPAL, D.V., BUTTTMER, S.M., McCUTCHEON, S.R., and CHANDRA, J. 1979. Geology and Mineral deposits, Caledonia area. New Brunswick Department of Natural Resources and Canada Department of Regional Expansion, Memoir 1, 213 p.

SUGDEN, D.E. and JOHN, B.S. 1976. Glaciers and Landscape. Edward Amold, London, 376 p.

SUPPE, J. 1985. Principles of Structural Geology. Prentice-Hall, Incorporated, New Jersey, 537 p.

TANOLI, S.K. 1987. Stratigraphy, sedimentology, and ichnology of the Cambrian-Ordovician Saint John Group, southern New Brunswick, Canada. Unpublished Ph.D. thesis, University of New Brunswick, 306 p.

TANOLI, S.K. and PICKERILL, R.K. 1988. Lithostratigraphy of the Cambrian-Lower Ordovician Saint John Group, southern New Brunswick. Canadian Journal of Earth Sciences, 25, pp. 669-690.

TUKEY, J.W. 1977. Exploratory Data Analysis. Addison-Wesley, Reading, Massachusetts, 330 p.

WALCOTT, R.I. 1970. Isostatic response to loading of the crust in Canada. Canadian Journal of Earth Sciences, 7, pp. 716-727.

WARDLE, R.J. 1978. The stratigraphy and tectonics of the Green Head Group; its relation to Hadrynian and Paleozoic rocks, southem New Brunswick. Unpublished Ph.D. thesis, University of New Brunswick, 294 p.

YANG, J.P. and AGGARWAL, Y.P. 1981. Seismotectonics of northeastem United States and adjacent Canada. Joumal of Geophysical Research, 86, pp. $4981-4998$.

YERKES, R.F., ELLSWORTH, W.L., and TINSLEY, J.C. 1983. Triggered reverse fault and earthquake due to crustal unloading. northwest Transverse Ranges, California. Geology, 11, pp. 287. 291. 